\title{
Earnings Management under Information Asymmetry at Initial Public Offerings in EGYPT: An Empirical Study
}

\author{
Shrouk Fathy Mohammed Abd EI Moula El Shafey \\ Accounting Department, \\ Faculty of Commerce, \\ Tanta University, Tanta, Egypt
}

Earnings Management under Information Asymmetry at Initial

Public Offerings in EGYPT: An Empirical Study

Shrouk Fathy Mohammed Abd El Moula El Shafey

Accounting Department, Faculty of Commerce, Tanta University, Tanta, Egypt 


\begin{abstract}
Purpose - The purpose of this thesis is to explore earnings management under information asymmetry at initial public offerings (IPO). More specifically, the researcher tried to explain the opportunities and incentives of earnings management at IPO and how firm managers may exploit the discretion available to them in manage earnings.
\end{abstract}

Methodology/Approach - The researcher depended upon the positive approach in analyzing the problem, explaining its causes and predicting the behavior of this phenomenon in the future.

Findings -the results indicated that IPO Egyptian firms use earnings management during the year of IPO in order to induce investor to buy their shares to maximize their IPO proceeds and also show that a higher level of increase in accruals is accompanied by a higher level of information asymmetry in the IPO year compared with the Pre-IPO year \& the Post- IPO year.

Research Limitations - This study is applied on a sample of companies listed on the Egyptian Stock Exchange. All study data and results for Egyptian companies only.

Originality/Value - This study contributed to the literature by providing explanation of the phenomenon of earnings management and its motivations at IPO. Moreover, this study exhibits opportunities of earnings management through discussing some techniques of earnings management in details.

Key Words: IPO, Earnings Management (EM), Information Asymmetry, Agency Theory.

\title{
1. Introduction:
}

Providing useful information for investors to predict the economic unit's performance is the primary purpose of financial accounting. Investors, executives and analysts' decision-making need to report earnings which help in providing criteria for evaluating the success of the company's performance, providing a basis for tax calculation, managing the distribution of earnings, determining the amount of divisible earnings, managing an economic unit and 
other items. The management often engages in earnings management through the manipulation of real activities or accounting figures to mislead shareholders regarding the company's actual economic performance or to influence contractual outcomes that depended on reported accounting numbers. This leads to increase the risk and uncertainty of the people outside the organization, reduce the accuracy of the earnings messaging and results in an asymmetric information and reduction in the efficiency of investment. This practice is more extensive at IPO firms because of the desire of management to increase its introductory prices in order to maximize the proceeds from the offering. Therefore, managers have the motivation to manipulate earnings to ensure that the issue is fully subscribed because their compensation and/ or reputation based on the success of the IPO.

The purpose of this research is to identify the timing of earnings management at IPOs in Egyptian companies listed on the Egyptian Stock Exchange and provide an empirical study detecting earnings management by Egyptian companies while going public.

\subsection{Research Problem:}

Because of information asymmetry and the lack of precise information about IPO firms, issuers can report unusually high earnings by adopting discretionary accounting accrual adjustments or through real earnings management that raise reported earnings relative to actual cash flows. The buyers could pay too high a price if they are guided by earnings but unaware that earnings are maximized by manipulating them. So that this study will emphasize on this problem at IPOs in Egyptian companies which represents in that:

- IPO in Egypt according to securities law 95 for 1992.

- Disclosure requirements for companies when they go public.

- Possibilities of earnings management at IPO.

- The relationship between asymmetric information and earnings management.

- Luck of empirical studies detecting earnings management by companies while going public.

\subsection{Research Objectives:}

The main objective of this study is to study earnings management under Information Asymmetry around the time of initial public offerings (IPOs)

for Egyptian companies listed on the Egyptian Stock Exchange.

This main objective can be achieved through the following sub- objectives:

1) Identifying timing of earnings management in IPO Egyptian firms.

2) Determining the relationship between Information Asymmetry and Earnings Management. 


\subsection{Research Importance:}

The research derives its significance from both academic and practical point of view:

In the academic sense, Researchers have advanced competing opinions about the proposal that initial public offering (IPO) companies engage in earnings management in the annual periods adjacent to their stock offerings. On one hand, some researchers argued that IPO companies have compelling objectives to manage upwardly assets and earnings to inflate the proceeds from the offering (Teoh et al.1998b; Aharony et al., 1993 and Friedlan, 1994). On the other hand, other researchers argued that IPO companies cannot systematically manage upwardly assets and earnings as this behavior would attract various monitors' attention such as boards, underwriters and auditors (Armstrong et al. 2008; Ball and Shivakumar 2008).

In practical view, it is significant to protect the funds of current and prospective investors and stakeholders and to help them make decisions that are based on accurate and reliable financial reports. Because if IPO firms report unusually higher earnings in order to increase their proceeds from IPO through applying real earnings management that raise reported earnings relative to actual cash flows or adopting discretionary accounting accrual adjustments, the investors will pay too high a price when they are guided by earnings but unaware that earnings are maximized by manipulating them.

\subsection{Research Methodology:}

To achieve the objective of the research; the researcher will depend upon the positive approach in analyzing the problem, explaining its causes and predicting the behavior of this phenomenon in the future which means explaining, analyzing and predicting the phenomenon of earnings management that firms may engage in it while going public.

The remainder of this research is organized as follows: Section 2 Literature Review; Section 3 Theoretical Framework; Section 4 Empirical Study; Section 5 Conclusions, Recommendations and Suggestions for Future Research.

\section{Literature Review}

Earnings management is a purposeful intervention in the external financial reporting process, with the intent of obtaining some private gain (Schipper,1989). According to Healy and Wahlen (1999), earnings management occurs when managers use judgment in financial reporting and in structuring transactions to alter financial reports to either mislead some stakeholders about the underlying economic performance of the company, or to influence contractual outcomes that depend on reported accounting numbers. In this vein, El Diri (2017) states, "Earnings management as the management discretion within GAAP to handle external financial reporting by abusing certain contracting shortcomings, restricted rationalities of stakeholders, and asymmetric information in the market by certain economic decisions, a 
modification in the accounting treatment, or other sophisticated methods. The management's aim is to display earnings differently (up or down) from what they know to obtain private benefits while misleading the stakeholders; although such discretion may not be detrimental to them at all".

Earnings management in the IPO process has attracted growing attention in accounting research. Earnings management in the IPO process is of particular concern because of the extent of information asymmetry between the ownersmanagers and investors (Leland and Pyle 1977), and between informed and uninformed investors (Rock 1986; Beatty and Ritter 1986). Because little information is available about these firms prior to going public, investors have to rely extensively on the prospectus for relevant financial information. The information asymmetry between management and related parties creates an opportunity for management to engage in earnings management. A positive relationship exists between the levels of information asymmetry and earnings management which suggests that information asymmetry is a necessary condition for earnings management (Richardson, 2000). According to, Dechow and Skinner (2000) indicate that managers can enhance the terms of the public offer and provide direct monetary benefits to themselves and their firm if they can increase reported earnings without detection. Because of the extent of asymmetric information between the investors and IPO issuers, earnings management is highly pertaining to IPOs. Managers may engage in earnings management to increase its introductory price as there is no previous market price for shares and because their reputation and compensation is based on the success of the IPO, They have an incentive to manipulate earnings to ensure that the issue is fully subscribed. Farooq and Benali (2012) state that the presence of earnings management practices by firms considering having an IPO and different levels of earnings manipulation are allowed by the presence of different incentives during the life cycle of a firm and argue that firms have the incentive to build a reputation as a profitable entity during the pre-IPO years through overstating accounting information to attract potential investors and establish a base for the sales of shares during the IPO. Similarly, Aharony et al. (2000) document that during the pre-IPO years, IPOs firms' accounts receivables are abnormally high. The initial value of firm and its proceeds from IPO can be increased by the higher pre-IPO discretionary accruals increase (DuCharme et al., 2001).

Several Studies document that the firms significantly manipulate their earnings during the year of IPO. For example, Teoh et al. (1998a) show that during the IPO year, firms can improve their financial statements through using accruals. Similarly, Teoh et al. (1998b) find that high discretionary accruals in the year of IPO which are followed by low cash flows and a greater drop in net income in subsequent years and there is a significantly negative relationship between discretionary accruals and the firm's age and the shareholdings' fraction retained by the issuer.

Management's desire to increase offering proceeds leads to enhance the amount of fund available for investing and increase the capital resources of firms. According to Roosenboom et al. (2003), managers may be induced to 
manage earnings upward during the IPO year as they are under a considerable pressure to reach the forecasts made in the period of introduction to avoid the legal lawsuits by discontented investors. Relatedly, Ibbotson (1975) and Mikkelson et al. (1997) indicate that the newly public firm's initial financial statements will contain unusually high positive accruals if firms increase earnings before selling stock and this increase in earnings management behavior results in declining in the post-IPO earnings.

In this vein, Bao et al. (2013) show that IPO firms not only manipulate earnings but also engage in real activities manipulation to inflate reported earnings and find that earnings manipulation in IPO firms is negatively associated with the reputation rankings of underwriters and the presence of venture capital and positively associated with the amounts of IPO proceeds. Accordingly, Cheng et al. (2015) reveal that firms tend to inflate earnings around their IPOs and find that non-state-owned enterprises manage earnings to a greater degree than stateowned enterprises. While Alhadab et al. (2016) show that during the IPO, firms on the lightly regulated AIM (UK Alternative Investment Market) have higher levels of accrual-based and sales-based earnings management and lower levels of discretionary expenses-based manipulation compared to those firms that list on the more heavily regulated Main market. Relatedly, Gulec et al. (2016) state that managers emphasize on increasing accruals to gain more proceeds for IPO process before going public and indicate that discretionary accruals level is the highest in the IPO year to affect the share prices and firms' profitability positively. Also, Shette et al. (2016) provide evidence that IPO companies' earnings and market performance are abnormally higher in the year of IPO. Finally, Gounopoulos and Pham (2018) show that newly listed firms with financial expert CEOs engage less in both real and accrual-based EM in the year of IPO than those with non-financial expert CEOs.

From the previous studies, it is clear that managers can report unusually high earnings by adopting discretionary accounting accrual adjustments and through real earnings management that raise reported earnings before and during the year of IPO because of the desire of management to induce investors to invest in their stocks.

\section{Theoretical Framework}

\subsection{An Overview of Initial Public Offering (IPO) at Egypt}

There are conditions for listing securities on the Egyptian Stock Exchange and procedures for conducting an IPO ("Rules of Listing and Delisting 
Securities..." 2020). So this research will display an overview of initial public offering (IPO) at Egypt according to these rules.

\subsubsection{The Concept of Initial public offering (IPO)}

Is the process of offering and distributing the firm's shares for the first time on the stock exchange to the public. This makes the shareholders own part of the firm's ownership based on the shares they have purchased. After going public, the firm's ownership will be owned by a large number of the small shareholders, not by one owner or group of partners, who have no right to the decisions made by the firm. As only the major shareholders are responsible for making decisions.

Firms that want to go public must fulfill the general conditions for listing on the Egyptian Stock Exchange Tables (which require prior registration with the Financial Regulatory Authority), which are:

- The securities of the firm must be registered in the central depository and registration system

- The basic system of the issuer or the conditions of issuance must not include any restrictions on trading the securities required to be registered, without prejudice to the restrictions contained in the legislation governing some activities or certain geographical areas.

- All issued securities of the same type must be registered, as well as the registration of the following issues and the right of priority to IPO according to the provisions contained in these rules.

- The firm requesting registration must commit to establishing a website on the international information network as soon as the registration of any of its financial papers in the stock exchange and before trading begins to publish the annual and periodic financial statements and the accompanying explanations thereof, and other data and information specified by the stock exchange management, among what companies must notify them according to these rules. Alternatively, the aforementioned data may be published on a site designated by the stock exchange for that purpose.

- The registration application and its attachments must be submitted through the legal representative of the entity requesting registration or through a registration agent accredited by the Stock Exchange in accordance with the controls specified by the implementation procedures of these rules.

- The entity requesting the registration of its securities must enter into a contract with the Stock Exchange that regulates the rights and obligations of each of them, including the obligations of the entity requesting the registration resulting from the violation of the rules and procedures of registration or the provisions of the contract.

- The necessity of using the cumulative voting method in the election of members of the Board of Directors to allow proportional representation in the membership of the Board of Directors whenever possible. 
- The formation of the company's board of directors must include at least one female element.

- Prohibition of combining the position of Chairman of the Board of Directors with the position of Managing Director or CEO of the firm.

\subsubsection{Procedures for Initial Public Offerings (IPO) at Egypt}

Firms that want to offer their shares for going public must follow the following procedures:

- The underwriter must pay the value of the share in cash, as well as the fees related to the issue.

- The individuals in charge of the firm must submit the original prospectus for the offering, and before the IPO process begins, they must specify their position thereof or those who represent them.

- The auditor's report on the validity of the data contained in the IPO prospectus must be attached and must be consistent with the law and with the initial firm contract and the own basic system of the firm.

- The percentage of shares to be offered must not be less than $25 \%$ of the total listed shares of the firm or a quarter per thousand of the market capital that is free to trade on the stock exchange, and not less than $10 \%$ of the firm's shares. In the application of this condition, the offering means to offer the firm's shares for sale on the stock exchange based on an offering prospectus or a disclosure report under the imposition of the offering approved by the Authority that includes what the independent financial advisor's study concluded with determining the fair value of the share and the auditor's report on this study in accordance with the relevant auditing standard, provided that neither of them shall be published in accordance with the rules established by the Authority's Board of Directors.

- The number of shareholders in the firm after the offering must not be less than 300 shareholders, taking into account that the shares allocated are distributed in light of the controls set by the stock exchange in order to verify that the offering is not fictitious.

- The percentage of shares that are free to trade must not be less than $10 \%$ of the total shares of the firm, or 1/8 per thousand of the market capital, free to trade on the stock exchange, and not less than $5 \%$ of the company's shares.

- The number of issued shares required to be registered must not be less than 5 million shares.

- The firm requesting registration must submit the financial statements for two fiscal years preceding the registration application. These statements must be prepared according to the Egyptian accounting standards and reviewed according to the Egyptian auditing standards by one of the auditors registered in the Authority's register and certified by the 
General Assembly of the firm and their records are documented by the competent administrative authority.

- The issued capital must be fully paid and not less than 100 million Egyptian pounds or its equivalent in foreign currencies, based on the latest annual or periodic financial statements accompanied by a comprehensive audit report from the auditor and certified by the General Assembly of the firm, and the shareholders 'equity in the last annual or periodic financial statements prior to the date of the registration request is not less than the paid capital.

- Submitting pledges that the percentage of the main shareholders of the company will not be less than $51 \%$ of the shares owned by them in the company's capital, if available, and if the total shares held accordingly are less than $25 \%$ of the issued company's shares, the percentage of 25 will be completed from the contributions of the members of the board of directors and the founders of the company or other shareholders of the company, for a period not less than two fiscal years from the date of the offering in the stock exchange or from the date of registration for companies whose shares were offered to the public in the issuance market before registration, provided that the same previous percentage is kept in any increase of the company's capital for the same period, with the exception of the bonus shares. And it is permissible - after the approval of the Authority and the Ordinary General Assembly of the company - to transfer the ownership of the shares held - part or in full - during the aforementioned retention period in the case that the buyer is a bank, an insurance company, a direct investment fund, an investment entity or a legal person with distinguished experience in the field of the company's activity and pledges to abide by the condition of retention until the end of the prescribed period.

- Among these procedures, it is allowed for firms that are established by offering their shares in a public offering and do not issue financial statements for two consecutive years to register their shares if they fulfill certain conditions, which are: "The issued and paid capital of the firm whose shares are required to be registered is not less than one million pounds, and the total number of shares owned by major shareholders is not less than $51 \%$ of the company's capital, and the percentage of shares that is free to trade is not less than at least $15 \%$ of the company's total shares, and that the number of the company's shareholders is not less than 1000 shareholders, and the number of issued shares are required to be registered is not less than for 20 million shares."

- The percentage of net profit before tax deduction for the last fiscal year preceding the registration application must not be less than 5\% of the paid capital required to be registered, provided that net profit of the firm before tax deduction are generated from exercising the firm's activity achieving the firm's purpose stated in its basic system and the percentage of net profit before tax after its calculation on an annual basis in the 
periodic financial statements in which the capital required to be registered and the following periodic financial statements - in the case of completion of their preparation- must not be less than $5 \%$ of the capital weighted by the period.

In all cases, it is not permissible to deal on the company's shares during the period from the date of registration until the start of trading on these shares except with the approval of the Authority. The registration is considered as if it was not if the firm does not offer its shares within one month from the date of its registration with the Authority. This period may be extended with the approval of the Authority in the cases it estimates.

\subsubsection{Initial Public Offerings (IPO) Steps:}

There are a number of steps to offer the firms' shares, these steps are as follows: First: Offering Share

is the process of offering the shares of private firms to the public on the stock exchange for the first time.

\section{Second: Preserving the Primary Owner}

when a particular firm goes public, this will lead to the preservation of private ownership, which is greater for the primary owner of the firm, and thus preserve its own decisions.

\section{Third: The Reasons for Offering the Shares}

The most significant reason that leads firms to offer their shares is raising funds to invest them in new acquisitions and new investments to pay off existing debts.

\section{Fourth: Evaluating the Share Price}

In this step, the firm evaluates the price of its shares periodically in order to make its shares publicly traded, and assesses the turnout of investors. So the firm, which lists its shares in the capital market, forms the market authority and this enjoys credibility and independence.

\section{Fifth: The Company's Performance and Stock Control}

In the last step, the increase in the value of the shares of the firm indicates the high demand for the shares and the good performance of the firm. However, a decline in the price of shares reflects the bad performance and a decline in the profits so the performance of the firm is measured by monitoring the turnout or the decline of shares.

\subsubsection{The Process of Initial Public Offerings (IPOs):}

The IPO process can be divided into different phases that are depended upon the activities included in each phase.

Each phase will be presented in the following (Katti and Phani, 2016):

\section{1) Research:}


Is the first step in the process after the firm decides to go public. This step contains research related activities which are significant to initiate the process of IPO. Once a firm takes a decision of going public, it normally assigns underwriters who carry out the process on behalf of the issuer to facilitate the process of IPO. the research division carries out a process of due diligence through evaluating macroeconomic indicators such as GDP growth, IPO cycles, savings and investment ,inflation, trends in the capital market, market timing and impact of other IPO reaching market around the same time during this initial phase. Also, it searches about the industry specific information such as capital structure of the industry, industry returns, various financial ratios that are specific to the industry and overall industry growth and its potential in the future.

\section{2) Underwriting:}

After research, the next step in IPO process is underwriting. This phase includes the preparation of draft prospectus that should be filed with the company's registrar and regulatory authorities and the data that are collected in the research phase can be used as an input for preparing the document. It determines the syndicate structure of the investment banks which are involved in the issue. In addition, it requires fulfillment of other requirement as approval from the exchange through which the securities are listed and traded. Lead manager plays a significant role in this stage. Through the consultation with the issuer, Lead manager decides to choose co-managers and other underwriters based on size of the issue and the geographical requirement.

\section{3) Marketing:}

Publicity and marketing of an issue is the third phase in the IPO process. With the help of other syndicate members, lead manager conducts the road show in different geographical locations to maximize the awareness of the retail investors about the issue and also publicizes the issue to different institutional investors through road shows. The advertising and media coverage are considered as an important factor in attracting the investors.

\section{4) Price Determination:}

This stage includes coordination among large numbers of activities once the issue opens and involves receiving the bids from various classes of investors, recording the price and quantity demanded, tracking the payment and changes if the bids are revised. This process includes lot of data handling. Automated system displays the status of the book which is maintained at the end of the day depended upon everyday demand until the closeness of issue to match the bids with price and quantity. Through consultation with the issuer, underwriter determines the final offer price based on the demand. If the process follows the book building mechanism, it is more or less same in any country. The process follows 
different method to finish the offer process in the case of auction or fixed price. A larger variation in terms of price determination has been observed by these two processes in different economies. However, in most of the countries auction process is largely discontinued and very few countries still choose fixed price method where the underwriter in consultation with the issuer determines the offer price before issue open date.

\section{5) Allocation:}

Allocation of the shares to the prospective investors is the next phase of the IPO process. The bids that are collected in the previous stage will be processed to determine the price which is treated as a cut off price for the allocation purpose. Underwriters have the discretionary power of allocation in many countries. In case if the underwriter does not have a discretionary power, the allocation of the shares will take place on prorata basis where the oversubscription ratio determines the number of shares allocated to each investors and this is implemented in India.

\section{6) Listing and Trading:}

Listing of securities on the exchange is the final phase in the process of IPO. It normally takes place within a week after the allocation process is finalized.

These previous phases that involved in the process of IPO can be summarized in the following Figure:

Figure (1): Different Phases of IPO Process

\begin{tabular}{|c|c|c|c|c|c|}
\hline $\begin{array}{l}\text { Due } \\
\text { diligence, } \\
\text { Industry, } \\
\text { Market } \\
\text { Return \& } \\
\text { Economic } \\
\text { Indicators }\end{array}$ & $\begin{array}{l}\text { Draft } \\
\text { Prospectus, } \\
\text { Regulatory } \\
\text { compliance } \\
\text { \&Syndication }\end{array}$ & $\begin{array}{l}\text { Publicity, } \\
\text { Advertisement } \\
\text { \& Road Show }\end{array}$ & $\begin{array}{l}\text { Collection of } \\
\text { bids \& Final } \\
\text { price } \\
\text { determination }\end{array}$ & $\begin{array}{l}\text { Allocation } \\
\text { to different } \\
\text { classes of } \\
\text { investors }\end{array}$ & $\begin{array}{l}\text { Secondary } \\
\text { Market } \\
\text { Trading, } \\
\text { Market } \\
\text { making \& } \\
\text { Price } \\
\text { stabilization }\end{array}$ \\
\hline
\end{tabular}

\subsection{Earnings Management at IPO}

Earnings management has been an area of concern for researchers and investors alike, for a long time now. While the existing listed companies also resort to earnings management, the practice is more rampant in the case of companies coming out with their initial public offerings (IPOs). This is largely due to the fact that not much information on the financial health and performance of the company is available in the public domain prior to the public issue. According to Ronen and Yaari (2008), earnings at IPOs are important because some investors may request information about earnings before buying stocks and subsequently will compare future performance of firms with the IPO earnings. 
IPOs are associated with high asymmetric information between management and shareholders because little information about the firms is known before going public (Cheung and Krinsky, 1994). Also, the price at which shares can be issued is predominantly a function of the perceived value of the shares of the company. Thus, this results into information asymmetry between the IPO firms and the potential investors. The companies therefore have the motivation to engage in income-increasing earnings management in order to raise the proceeds from the offering and affect the valuation of their firms in the market (Fan, 2007). They tend to report stable and better financial results, though still complying with the prevailing accounting principles and standards.

There are two alternatives concerning the timing of earnings management in IPO firms which are represented in:

The first alternative is related to using income-increasing accruals before the IPO. Managers may seek to income-increasing accruals to achieve higher offer prices if investors rely extensively on financial statement disclosures in pricing IPO shares. This leads to that management resorts to use income-increasing accruals to increase the offering proceeds before going public. Prior to the IPO, Companies which publish an interim report manipulate earnings in it and not in the full year financial statements before the IPO. According to Friedlan (1994), at the time of the IPO, Managers manage earnings in the most recent financial statement to increase the offer price. On the other hand, Aharony et al. (1993) find that in the years before the IPO, earnings management is lower.

The second alternative involves managers, who seek to sell their shares, have an incentive to use income-increasing accruals during the first year as a public company to boost high stock prices of the firm after IPO. There is another reason for manipulating earnings in the first financial year as a public company is to meet earnings forecasts issued at the time of the IPO which are considered as a pressure on the firm to achieve them especially those firms that experience an unexpected decrease in cash flows in that same year. In this vein, Magnan and Cormier (1997) find that IPO firms manipulate earnings during the first year as a public company to meet their voluntary forecasts made at the IPO time.

\subsection{Agency Theory}

Holmstrom and Milgrom (1987) according to the previous work of Jensen and Meckling (1976) establish the agency theory which is also referred to as the principal-agent theory. It assumes that the employment contract involved two parties: the agent (manager) and the principal (shareholder). A problem of information is the main problem between the principal and the agent because a situation of information asymmetry arises when the manager is more informed than the shareholders. This creates an opportunity for adverse selection by management. In this vein, Harris and Raviv (1979) mention that moral hazard is an incentive problem which also contributes to the agency problem. It is resulted from the different motivations and attitude towards risk by the different 
decision makers. Moral hazard and adverse selection lead to the problem of coordination in making decisions regarding who makes the decision, what information is reported and how it is communicated. So, when shareholders try to maintain some control over the performance of managers, they delegate the task of decision making to managers. The agency problem is also resulted from the different objectives and preferences of the principals and agents. Specialized risk bearing and specialized decision skills in the organization are found due to the separation between ownership and control. In this sense, Strong and Walker (1987) find that maximizing the utility function is the objective of each party and ultimately the agent's effort is depended on the overall agency payoff.

According to Giroux (2004), different behaviors of management ranging from obedience to self-interest and further to opportunism that involves earnings manipulation is resulted from the difference in the intensity of the agency problem. The agency problem has covered other parties as creditors, major and minor shareholders and is not only limited to the principal and agent.

Because of a conflict of interest between controlling shareholders (issuers) and non-controlling shareholders (underwriters) which is known as agency conflict Type II, issuers can report unusually high earnings through real earnings management and by adopting discretionary accounting accrual adjustments that raise reported earnings before and during the year of IPO to make investors invest in their stocks. In this vein, Ratnawati et al. (2016) examine the influence of agency conflict Type II which is represented by control rights, cash flow rights and cash flow rights leverage on earnings management and find that control rights have the greatest effect on earnings management. Whereas control rights indicate the right to participate in decisions about the company among controlling shareholders and may affect the company's policy and allow the occurrence of the expropriation of the minority shareholders by controlling shareholders. Controlling shareholders will seek to implement policies and incentives and allocate the company's resources to obtain private benefits over the minority shareholders when the majority shareholders have the control. So, the higher the control rights indicate the higher earnings management (Claessens et al., 2000). However, Cash flow rights consider a source of financial incentives to limit the expropriation which minimize earnings management (Siregar, 2008).

According to Sanjaya (2010), cash flow rights include direct and indirect cash flow rights. The percentage of shares owned by shareholders in a public company on its own is considered direct cash flow rights while indirect cash flow rights represent the number of shareholders multiplied by the percentage of ownership in each chain of the ownership. So, the sum of the percentage of direct and indirect cash flow rights is referred to the cash flow. Finally, Cash flow rights leverage is the deviation between cash flow rights to control right which increase over the controls through a variety of mechanisms such as pyramid ownership and cross-ownership (Siregar, 2008). Majority shareholders intervene opportunistically in determining the policies of the company to obtain private benefits by earnings management through cash flow rights leverage. Thus, the higher cash flow rights leverage, the higher the tendency of 
controlling shareholder to expropriate non-controlling shareholders and the greater the likelihood of the agency problem. Therefore, there are conditions to motivate controlling shareholders to manage earnings (Gugler and Yurtoglu, 2003).

The conflict between majority and minority shareholders is also happened because of concentrated ownership setting where major shareholders have privilege to choose the corporate organ like a commissioner board and a board of directors who give their loyalty to a major shareholder that has a power to hire or dismiss them. In a concentrated ownership setting, the majority can monitor management's activities resulting in minimizing management behaving self-interest, but the majority can take advantages private information. In this vein, Bar-Yosef and Prencipe (2013) provide evidence that there is a positive relationship between concentrated ownership and bid-ask spread which indicates less extensive accounting disclosure or information asymmetry. However, higher concentrated ownership has lower volume trade which means willingness to transact.

The study of Nurim, et al. (2017) aims to detect the tendency of management doing earnings management as whether management faces type II agency conflict in firms that listed in IDX from 2009-2014 based on reputation quality through auditor quality ( big $\mathrm{N}$ or non big $\mathrm{N}$ ), membership of Jakarta Islamic Index and LQ45. It reveals that auditor quality, membership of JII and LQ 45 have a significant negative relationship with earnings management which results in reducing the aggressive earnings management behavior. It also shows that auditor quality may become a good signal for investors whereby management shows their commitment for reporting a reliable financial statement to maintain investor's interest through more perceived honorable reputation than non big $\mathrm{N}$. This result indicates that because earnings management behavior has an objective to enhance good signal for investor, management faces type II agency conflict.

\subsection{Information Asymmetry}

Information Asymmetry is a situation where the manager has access to more information on the future prospects of the company than the shareholders (owners) and other stakeholders (Lasdi, 2013). Information asymmetry may be anticipated by the disclosure of information more qualified. The manager is therefore obliged to provide the owner with signal information on the status of the company. However, often the information submitted does not comply with the actual conditions because it allows managers to manage their earnings. According to Richardson (2000), the problem of information asymmetry arises when managers or insiders have more information than other external shareholders. So, the managers or controlling shareholders can protect their private interest through applying earnings management which escalates the problem of information asymmetry.

Information Asymmetry plays an important role in the conflict between controlling shareholders and minority shareholders (agency conflict type II). Controlling shareholders can obtain private information because of their 
closeness to management and therefore do not publicly disclose information to avoid minority contests (Johnson et al., 2000). In this vein, Fan and Wong (2002) find less credibility in reported earnings because controlling shareholders report accounting information for self-interested purposes. Also, controlling shareholders have objectives to minimize and delay corporate disclosure to increase the chance of executing their plans or to make sure minority shareholders' decisions are depended on inappropriate information (Attig et al., 2006).

The existence of information asymmetry between managers and shareholders is a necessary condition for earnings management (Dye, 1988). According to Demsetz (1968), a wider bid-ask spread (a measure of information asymmetry) will be posted in stock prices by external or non-controlling shareholders to reduce their potential losses. This will benefit controlling shareholders to obtain abnormal profits before their share prices are adjusted by the market to their real value because of the informational disadvantages. If external or non-controlling shareholders adopt a buy and hold strategy, their returns reduce and lead to losses. So the magnitude of information asymmetry affects the magnitude of earnings management practiced by firm managers. If information asymmetry is high, stakeholders do not have the necessary information and sufficient resources, incentives to "see through" the managed earnings (Schipper, 1989), while low information asymmetry can increase companies' earnings quality which promotes effective monitoring and encourages company management to publish reliable earnings information by expanding information channels and increasing information transparency (Dai et al., 2013). In this vein, Richardson (2000) provides evidence that there is a positive relationship between earnings management and the level of information asymmetry by using the bid-ask spread and the dispersion in analysts' forecasts as measures of information asymmetry. He suggests that outside monitors who represent in the proportion and strength of outside members of the board of directors, the strength of the audit committee, controlling shareholders and focused firm stakeholders such as labor unions and firm suppliers can diminish management action and management's accounting choices to limit the extent of earnings management performed by firm managers.

In the case of IPOs, the misalignment of incentives between management and potential investors may result in managing earnings opportunistically in the financial statements by managers surrounding the IPO. If market participants are not aware that earnings are inflated by the use of accruals, they will initially trade at overvalued prices. So the information about accruals may be more beneficial for users of financial statements to gradually arrive at a more accurate valuation of the firm over time than reported earnings (Chaney and Lewis 1995). Also, the study of Hernando (2018) examines the relationship between information asymmetry and earnings management in companies that carry out initial public offering on the Indonesia Stock Exchange and shows that information asymmetry has a significant positive relationship with earnings 
management during and after conducting an IPO. However, information asymmetry has no significant effect on earnings management before the IPO.

\section{Empirical Study}

The purpose of empirical study is to find evidence whether IPO Egyptian firms that listed on the Egyptian Stock Exchange report unusually higher earnings by adopting accounting accrual adjustments to attract potential investors and increase the offering proceeds.

Empirical Study includes hypotheses development, sample selection, data collection, study variables, statistical analysis of data and discussion of empirical results.

\subsection{Hypotheses}

An important implication that companies may engage in earnings management before the IPO year. However, earnings management during the year of IPO is much than it in the pre-IPO years because lesser earnings than the previous years would hurt the firm's reputation in the eyes of potential investors. So the motivation to overstate accounting information is the most during the IPO year. The firms significantly use accruals to manipulate their earnings to improve their financial statements during the year of IPO (Teoh et al. 1998a).

The management's desire to maximize the proceeds from the offering may be at the heart of such an opportunistic behavior to enhance the amount of fund available for investing and to increase the firms' capital resources. In addition, managers are under a considerable pressure in order to reach the forecasts made in the introduction period to avoid the legal lawsuits by discontented investors (Roosenboom et al., 2003). Therefore, managers may be induced to use incomeincreasing earnings management during the year of IPO.

Accordingly, the first and second hypotheses can be formulated as follows:

H1: IPO Egyptian companies show a greater increase in accruals (IncomeIncreasing strategy) in order to manipulate earnings in the IPO year compared with the Pre-IPO year.

H2: IPO Egyptian companies show a greater increase in accruals (IncomeIncreasing strategy) in order to manipulate earnings in the IPO year compared with the Post-IPO year.

There is an effect for the magnitude of information asymmetry on the magnitude of earnings management applied by firm managers. Stakeholders do not have the necessary information to "see through" the manipulated earnings if information asymmetry is high. Investors have to rely extensively on the prospectus for relevant financial information because little information is available about the firms before going public. 
Information Asymmetry has a significant role in the conflict between controlling shareholders and non-controlling shareholders. Controlling shareholders can benefit from private information because they are close to management and therefore do not publicly disclose information to avoid minority contests (Johnson et al., 2000).

Accordingly, the third and fourth hypotheses can be formulated as follows:

H3: Higher level of increase in accruals is accompanied with higher level of information asymmetry in the IPO year compared with the Pre-IPO year.

H4: Higher level of increase in accruals is accompanied with higher level of information asymmetry in the IPO year compared with the Post-IPO year.

\subsection{Study Variables:}

Study variables have been divided according to study hypotheses:

\section{According to $\mathrm{H} 1 \& \mathrm{H} 2$ :}

- Independent variable: IPO

- Dependent variable: Accruals (which are used as a proxy of earnings management).

\section{According to $\mathrm{H} 3 \& \mathrm{H} 4$ :}

- Independent variable: Accruals.

- Dependent variable: Information Asymmetry (which is measured by the difference between high and low price of the share divided by low price of the share for each company).

Total Accruals are computed according to the following equation:

$$
\mathbf{T A}_{\mathrm{i}, \mathrm{t}}=\Delta\left(\mathrm{CA}_{\mathrm{i}, \mathrm{t}}-\operatorname{Cash}_{\mathrm{i}, \mathrm{t}}\right)-\Delta\left(\mathrm{CL}_{\mathrm{i}, \mathrm{t}}-\text { Overdraft }_{\mathrm{i}, \mathrm{t}}\right)-\mathrm{DEP}_{\mathrm{i}, \mathrm{t}}
$$

\section{Where:}

$\mathbf{T A}_{\mathrm{i}, \mathrm{t}}$ : Total accruals for firm $\mathrm{i}$ in period $\mathrm{t}$

$\Delta\left(\mathbf{C A}_{\mathbf{i}, \mathrm{t}}-\mathbf{C a s h}_{\mathrm{i}, \mathrm{t}}\right)$ : Change in current assets excluding cash and cash equivalents for firm $i$ in period $t$

$\Delta\left(\mathbf{C L}_{\mathrm{i}, \mathrm{t}}\right.$ - Overdraft $\left.\mathrm{i}_{\mathrm{i}, \mathrm{t}}\right)$ : Change in current liabilities excluding overdraft for firm $\mathrm{i}$ in period $\mathrm{t}$

DEP $_{i, t}$ : Depreciation and amortization expense for firm $\mathrm{i}$ in period $\mathrm{t}$

\subsection{Sample and data Collection:}

The study is applied to a sample of 25 IPO Egyptian companies that are listed on Egyptian Stock Exchange. The sample was selected based on two criteria:

I. Each firm has an active trading on its shares. 
II.Availability of financial statements for each firm before, during and after going public and IPO prospectus.

The study interval is divided into: 1) the Pre-IPO year, 2) the IPO year, and 3) the Post-IPO year.

The required data are mainly collected from the financial statements and IPO prospectus of firms published on the following sites:

1) The Egyptian Stock Exchange: http://www.egx.com.eg/

2) Mubasher: http://www.mubasher.info/countries/eg

3) Investing: http://www.Investing.com

Table (1): A List of Companies Used In the Empirical Study

\begin{tabular}{|c|c|c|c|}
\hline No & Company Name & Sector & $\begin{array}{c}\text { The IPO } \\
\text { Year }\end{array}$ \\
\hline $\mathbf{1}$ & Ibnsina Pharma & $\begin{array}{c}\text { Healthcare \& } \\
\text { Pharmaceuticals }\end{array}$ & 2017 \\
\hline $\mathbf{2}$ & Emaar Misr for Development & Real Estate & 2015 \\
\hline $\mathbf{3}$ & Al Tawfeek for Financial Lease & Financial Lease & 2016 \\
\hline $\mathbf{4}$ & Arabian Rocks Plastic Industries & Chemicals & 2016 \\
\hline $\mathbf{5}$ & Misr Fertilizers Production Co & $\begin{array}{c}\text { Fertilizers \& } \\
\text { Agricultural } \\
\text { Chemicals }\end{array}$ & 2016 \\
\hline $\mathbf{6}$ & ObAE (MOPCO) & Food \& Beverage & 2016 \\
\hline $\mathbf{7}$ & Edita Food Industries SAE & Food \& Beverage & 2015 \\
\hline $\mathbf{8}$ & $\begin{array}{c}\text { MM Group For Industry And } \\
\text { International Trade (MTIE) }\end{array}$ & $\begin{array}{c}\text { Industrial Goods and } \\
\text { Services and } \\
\text { Automobiles }\end{array}$ & 2016 \\
\hline $\mathbf{9}$ & Arabian Food Industries Co & Food \& Beverage & 2015 \\
\hline $\mathbf{1 0}$ & Cleopatra Hospital Co & Healthcare Facilities & 2016 \\
\hline $\mathbf{1 1}$ & Juhayna Food Industries SAE & Food \& Beverage & 2010 \\
\hline $\mathbf{1 2}$ & Raya Contact Center & Software \& Services & 2016 \\
\hline $\mathbf{1 3}$ & Genial Tours & Consumer Services & 2014 \\
\hline $\mathbf{1 4}$ & Porto Group Holding & Real Estate & 2018 \\
\hline $\mathbf{1 5}$ & Telecom Egypt & Communications & 2005 \\
\hline $\mathbf{1 6}$ & $\begin{array}{c}\text { Egypt South Africa for } \\
\text { Communication }\end{array}$ & Communications & 2015 \\
\hline $\mathbf{1 7}$ & Amer Group Holding Co SAE & Real Estate & 2010 \\
\hline & & & \\
\hline
\end{tabular}




\begin{tabular}{|c|c|c|c|}
\hline $\mathbf{1 8}$ & Sky Light Touristic Development & Consumer Services & 2015 \\
\hline $\mathbf{1 9}$ & Vertika for Industry trade & Software \& Services & 2015 \\
\hline $\mathbf{2 0}$ & $\begin{array}{c}\text { Fawry for banking Technology } \\
\text { and Electronic payments SAE } \\
\text { (FWRY) }\end{array}$ & Software \& Services & 2019 \\
\hline $\mathbf{2 1}$ & $\begin{array}{c}\text { CI Capital Holding for Financial } \\
\text { Investments (CICH) }\end{array}$ & $\begin{array}{c}\text { The diversified } \\
\text { Financials }\end{array}$ & 2018 \\
\hline $\mathbf{2 2}$ & $\begin{array}{c}\text { Sarwa Capital Holding for } \\
\text { Financial Investments (SRWA) }\end{array}$ & $\begin{array}{c}\text { The diversified } \\
\text { Financials }\end{array}$ & 2018 \\
\hline $\mathbf{2 3}$ & $\begin{array}{c}\text { Dice Sport and Casual Wear } \\
\text { (DSCW) }\end{array}$ & $\begin{array}{c}\text { Consumer durables } \\
\text { \& Apparel }\end{array}$ & 2017 \\
\hline $\mathbf{2 4}$ & $\begin{array}{c}\text { Tenth of Ramadan Pharmaceutical } \\
\text { Industries \& Diagnostic }\end{array}$ & $\begin{array}{c}\text { Pharmaceuticals, } \\
\text { Biotechnology\& } \\
\text { Life Sciences }\end{array}$ & 2018 \\
\hline $\mathbf{2 5}$ & $\begin{array}{c}\text { MB for Engineering and } \\
\text { Contracting (MBEN) }\end{array}$ & $\begin{array}{c}\text { Capital Goods } \\
\text { Sector }\end{array}$ & 2015 \\
\hline
\end{tabular}

\subsection{Statistical Analysis of Data:}

Data analysis aims to analyze the data of the selected firm-year observations in order to test the hypotheses. To test study hypotheses three statistical procedures have been used; Descriptive statistical analysis, T-test and regression analysis. The descriptive analysis summarizes main features of data set. T-test is statistical technique, which is used to compare between the average values of the two data sets. Finally, regression analysis aims to explore the relationship between a dependent variable and an independent variable.

Since there are three statistical procedures that are employed throughout the study, this section is divided into three parts; each part includes a brief explanation of each technique in addition to the empirical results of using the technique. Statistical Package for the Social Sciences (SPSS, ver. 25.0) has been employed to analyze the sample data. Before testing the research hypotheses through inferential statistics, descriptive statistics of the data set is presented.

\subsubsection{Descriptive Statistics of Total Sample Study}

This section provides descriptive statistics for the variables that will be used to test the hypotheses. In the next table (2), descriptive statistics for variables are displayed. Descriptive statistics make it possible to summarize the central tendency of the data (the minimum and maximum values that each variable can take as well as the mean and the standard deviation) of the variables.

Table (2): Descriptive Statistics

\begin{tabular}{|c|c|c|c|c|c|}
\hline Variables & Observations & Mean & Std. Deviation & Minimum & Maximum \\
\hline$A C C b$ & 25 & -.036651177 & .1390369795 & -.475140491 & .1846211058 \\
\hline
\end{tabular}




\begin{tabular}{|l|l|l|l|l|l|}
\hline$A C C o$ & 25 & .0662554642 & .0971271813 & -.077008190 & .2920396898 \\
\hline$A C C a$ & 25 & .0183799325 & .0797409065 & -.160558808 & .1275282537 \\
\hline
\end{tabular}

\section{Where:}

ACC b: Accruals in the Pre-IPO year.

ACC o: Accruals in the IPO year.

ACC a: Accruals in the Post-IPO year

Table (2) presents descriptive statistics of variables for the sample. It shows that; the average ACC b is -.036651177, the standard deviation is .1390369795, the minimum amount is -.475140491 and the maximum amount is .1846211058 . It also shows that the mean of ACC $\mathbf{0}$ is .0662554642 and standard deviation is .0971271813 with a range from -.077008190 to .2920396898. Table (2) also shows that ACC a ranges from -.160558808 to .1275282537 with a mean of .0183799325 and a standard deviation of .0797409065 .

\subsubsection{T-test:}

The second statistical technique used in this study is T-test. This technique enables us to compare between the average values of the two data sets. In this study, we will use a paired t-test to determine the difference between two variables for the same subject (accruals) which are separated by time (the PreIPO year, the IPO year \& the Post-IPO year).

The following table summarizes the results of a paired t-test

Table (3): Paired t-test

\begin{tabular}{|c|c|c|c|c|c|c|}
\hline & Mean & $\mathbf{t}$ & Sig. & $95 \%$ Con & f. Interval & $r$ \\
\hline $\begin{array}{l}\text { Panel A: PO yeard Pre-IPU year } \\
A C C o-A C C b\end{array}$ & .1029066411 & 2.839 & .009 & .0280857335 & 1777275486 & -.151 \\
\hline $\begin{array}{l}\text { Panel B: IPO year\& Post-IPO year } \\
A C C o-A C C a\end{array}$ & .0478755317 & 1.898 & .070 & -.004193729 & 0999447921 & -.008 \\
\hline
\end{tabular}

For IPO year\& Pre-IPO year

The results show that there is a significant difference between accruals in the IPO year and in the Pre-IPO year (ACC o \& ACC b), $(\mathrm{t}=2.839, \mathrm{P}=.009$ which is smaller than .05), with an average increase of .1029066411, with $95 \%$ confidence limits of $(.0280857335, .1777275486)$ and also indicate that accruals in the IPO year and in the Pre-IPO year are negatively correlated $(r=-.151)$.

This result agrees with the study hypothesis that Egyptian IPO companies show a greater increase in accruals (income- increasing strategy) in order to manipulate earnings in the IPO year compared with the Pre-IPO year.

\section{- For IPO year\& Post-IPO year}


The results also show that there is a slight difference between accruals in the IPO year and in the Post-IPO year (ACC o \& ACC a), $(\mathrm{t}=1.898, \mathrm{P}=.070$ which is slightly greater than .05), with an average increase of .0478755317 , with $95 \%$ confidence limits of $(-.004193729, .0999447921)$ and accruals in the IPO year and in the Post-IPO year are negatively correlated $(r=-.008)$.

\subsubsection{Regression Analysis:}

Regression analysis examines the relationship between a dependent variable (predicted variable) and an independent variable (predictors). Further, this analysis is used to discover the significance and the predictive power of a regression model and to assess the extent of variation in the dependent variable that is explained by the independent variable variation. In other words, regression analysis helps to understand the extent of the dependent variable changes when the independent variable is changed.

\section{First: Regression analysis to determine the effect of IPO on accruals}

The following table summarizes the results of Regression analysis

Table (4): Regression analysis for the effect of IPO on accruals

\begin{tabular}{|l|c|c|c|c|}
\hline & R square & F-test & Sig. level & coefficient \\
\hline $\begin{array}{l}\text { Panel A: IPO year\& Pre-IPO year } \\
\text { IPO1 }\end{array}$ & .161 & 9.204 & .004 & .103 \\
\hline $\begin{array}{l}\text { Panel B: IPO year\& Post-IPO year } \\
\text { IPO2 }\end{array}$ & .070 & 3.628 & .063 & .048 \\
\hline
\end{tabular}

\section{Where:}

IPO1: Initial Public Offerings (Independent and binary variable which has two values, $0=$ the Pre- IPO year and $1=$ the IPO year).

IPO2: Initial Public Offerings (independent and binary variable which has two values, $0=$ the Post IPO year and $1=$ the IPO year).

\section{- For IPO year\& Pre-IPO year}

The results show that $\mathrm{R}$-square is 0.161 which means that $16.1 \%$ of the variance in accruals in IPO year \& Pre-IPO year (dependent variable) is explained by the independent variable (IPO1).The P-value of 0.004 and significance at 5\% which is statistically significance shows that the model fit the data well and should be used as a predictive or explanatory tool for the variations of the accruals variable. In addition the coefficient is equal to .103 which shows a positive relationship between IPO and accruals leading to the first hypothesis of the study to be accepted.

\section{- For IPO year\& Post-IPO year}


The results show that value of $\mathrm{R}$ square is very low, it can be noticed that the Rsquare is 0.070 which means that just $7 \%$ of the variance in accruals in IPO year \& Post-IPO year (dependent variable) is explained by the independent variable (IPO2). This is a very small portion. The significance is 0.063 which is slightly greater than 0.05 . So it can be inferred that the regression model is weak significant and explains the variations in accruals variable by a small portion. In addition the coefficient is equal to .048 which shows a weak positive relationship between both variables.

\section{Second: Regression analysis to determine the effect of accruals on Information asymmetry:}

The following table summarizes the results of Regression analysis

Table (5): Regression analysis for the effect of accruals on Information asymmetry

\begin{tabular}{|l|c|c|c|c|}
\hline & R square & F-test & Sig. level & coefficient \\
\hline $\begin{array}{l}\text { Panel A: IPO year } \\
A C C ~ o\end{array}$ & .284 & 9.101 & .006 & 1.061 \\
\hline $\begin{array}{l}\text { Panel B: IPO year\& Pre-IPO year } \\
\text { ch1 }\end{array}$ & .226 & 6.733 & .016 & .508 \\
\hline $\begin{array}{l}\text { Panel C: IPO year\& Post-IPO year } \\
\text { ch2 }\end{array}$ & .197 & 5.655 & .026 & .753 \\
\hline
\end{tabular}

Where:

ACC o: Accruals in the IPO year (independent variable).

ch1: Change in accruals (the difference between accruals in the IPO year \& in the Pre-IPO year).

ch2: Change in accruals (the difference between accruals in the IPO year $\&$ in the Post-IPO year).

\section{- For IPO year}

The results show that R-square equals 0.284 which means that $28.4 \%$ of the variance in asymmetry (dependent variable) is explained by the independent variable (ACC o). The P-value of 0.006 and significance at 5\%, which is statistically significance, shows that the model fit the data well and should be used as a predictive or explanatory tool for the variations of asymmetry variable. There is a positive relationship between accruals and information asymmetry since coefficient is equal to 1.061 .

\section{- For IPO year\& Pre-IPO year}

The results show that regression model is significant and should be used as a predictive or explanatory tool for the variations of the asymmetry variable since $\mathrm{R}$-square equals 0.226 which means that $22.6 \%$ of the variance in asymmetry 
(dependent variable) is explained by the independent variable (change in accruals [ch1]) and significance is 0.016 which is smaller than 0.05 . In addition the coefficient is equal to .508 which shows a positive relationship between both variables. This leads to the third hypothesis of the study to be accepted.

\section{- For IPO year\& Post-IPO year}

The results show that R-square equals 0.197 which means that $19.7 \%$ of the variance in asymmetry (dependent variable) is explained by the independent variable (change in accruals [ch2]). The P-value of 0.026 and significance at $5 \%$, which is statistically significance, shows that the model fit the data well and should be used as a predictive or explanatory tool for the variations of asymmetry variable. There is a positive relationship between accruals and information asymmetry since coefficient is equal to .753 resulting in accepting the fourth hypothesis of the study.

\subsubsection{Discussion of Empirical Results:}

The first hypothesis proposed by the study is supported by results of T-test and regression analysis. This means that IPO Egyptian companies show a greater increase in accruals in order to manipulate earnings in the IPO year compared with the Pre-IPO year to induce investors to buy their shares resulting in maximizing their IPO proceeds. But concerning the second hypothesis proposed by the study, the results of T-test and regression analysis do not support this hypothesis very well. It was found that a weak significant relationship between independent variable (IPO) and dependent variables (accruals in the IPO year \& in the Post-IPO year). The third and fourth hypotheses proposed by this study are supported by the results of regression analysis. This means that higher level of income-increasing accruals is accompanied with higher level of information asymmetry in the IPO year compared with the Pre-IPO year \& the Post-IPO year.

\section{Conclusion, Recommendations and Suggestions for Future Research}

\subsection{Conclusion}

The conclusion of this research is an analysis of the phenomenon of earnings management at initial public offerings (IPOs) in Egypt through literature review, the theoretical framework of the study and the results of empirical study. This study provides an overview on of Initial Public Offering (IPO) at Egypt through discussing the concept of IPO, procedures for IPO and IPO steps and displays the phenomenon of earnings management at IPOs and discusses the effect of agency conflict type II and Information asymmetry on earnings management. Then the empirical study is implemented and the study hypotheses are empirically examined by using a sample of 25 IPO Egyptian firms. There are different statistical procedures that have been used to test the study four hypotheses; this chapter exhibits three techniques; the descriptive statistical analysis, T-test and regression analysis. The descriptive statistical analysis summarizes the central tendency of the data of variables. While T-test 
is used to compare between the average values of the two data sets. Finally, regression analysis has been used to discover whether there is a significant correlation between the dependent variable and the independent variable. The study also provides discussions of the statistical procedures results. Based on these results, there are strong evidences on the practice of earnings management by IPO Egyptian firms in the IPO year and there is a positive relationship between income- increasing accruals and Information Asymmetry in the IPO year.

\subsection{Recommendations}

The following recommendations may contribute to limiting the practices of earnings management at IPO:

- The auditors must take into considerations opportunities for earnings management made by firms at IPO.

- Regulators must enact strict and deterrent laws and regulations on firms in the case that earnings management practices are found in their financial statements at IPO which leads to mislead investors about underlying economic performance of the firm.

\subsection{Suggestions for Future Research}

There are several areas that have not been covered by this research, which may useful for further study. Thus, there are numerous possible ways in which, the research study as a whole could be extended.

- One possible avenue for future research is to investigate whether and how IPO firms take actions to manage earnings downward at IPO in certain contexts. Past research on EM has exclusively focused on upward earnings management at IPO. Downward EM seems a fruitful area for future research.

- Future research should continue to explore how firm managers especially use real earnings management to manipulate earnings at IPO.

- Future studies should investigate the effect of IPO on the performance of firms after going public

\section{References}

- Aharony, J., C. Lin \& M. Loeb (1993). Initial Public Offerings, Accounting Choices, and Earnings Management. Contemporary Accounting Research, 10(1), 61-81.

- Aharony, J., C.-W.J. Lee \& T.J. Wong (2000). Financial Packaging of IPO Firms in China. Journal of Accounting Research, 38 (1), 103-126. 
- Alhadab, M., I. Clacher and K. Keasey (2016). A Comparative Analysis of Real and Accrual Earnings Management around Initial Public Offerings under Different Regulatory Environments. Journal of Business Finance \& Accounting, 43(7-8), 849-871.

- Armstrong, C., G. Foster \& D. Taylor (2008). Earnings Management around Initial Public Offerings: A Re-examination. Working paper. University of Pennsylvania, Philadelphia, PA.

- Attig, N., W.F. Fong, Y. Gadhoum \& L.H.P. Lang (2006). Effects of Large Shareholding on Information Asymmetry and Stock Liquidity. Journal of Banking and Finance, 30 (10), 2875-2892.

- Ball, R., \& L. Shivakumar (2008). Earnings Quality at Initial Public Offerings. Journal of Accounting and Economics, 45(2-3), 324-349.

- Bao, B.H., R. Chung, Y. Niu \& S. Wei (2013). Real and Accrual Earnings Management around IPOs: Evidence from US Companies. Journal of Corporate ownership and control, 10(3), 76-94.

- Bar-Yosef, S., \& A. Prencipe (2013). The Impact of Corporate Governance and Earnings Management on Stock Market Liquidity in a Highly Concentrated Ownership Capital Market. Journal of Accounting, Auditing \& Finance. 28 (3), 293-316.

- Beatty, R.P., \& J. Ritter. (1986). Investment Banking, Reputation, and the Underpricing of Initial Public Offerings, Journal of Financial Economics, 15(1-2), 213-232.

- Chaney, P. K., \& C.M. Lewis (1995, April). Earnings Management and Firm Valuation under Asymmetric Information. Journal of Corporate Finance, 1(3-4), 319-345.

- Cheng, C. S. A, J. Wang and S. X. Wei (2015). State Ownership and Earnings Management around Initial Public Offerings: Evidence from China. Journal of International Accounting Research, 14 (2), 89-116.

- Cheung, C. S., \& I. Krinsky (1994). Information Asymmetry and the Underpricing of Initial Public Offerings: Further Empirical Evidence. Journal of Business Finance and Accounting, 21(5), 739-747.

- Claessens, S., S. Djankov \& L.H.P. Lang (2000). The Separation of Ownership and Control in East Asia Corporations. Journal of Financial Economics, 58(1-2), 81112.

- Dai, Y., D. Kong \& Li. Wang (2013). Information Asymmetry, Mutual Funds and Earnings Management: Evidence from China. China Journal of Accounting Research, 6 (3), 187-209.

- Dechow, P., and D. Skinner (2000). Earnings Management: Reconciling the Views of Accounting Academics, Practitioners and Regulators. Accounting Horizons, 14 (2), 235-250.

- Demsetz, H. (1968). The Cost of Transacting. The Quarterly Journal of Economics, 82 (1), 33-53.

- DuCharme, L. L., P.H. Malatesta and E.S. Stephan (2001). Earnings Management: IPO Valuation and Subsequent Performance. Journal of Accounting, Auditing \&Finance, 16, 369-396.

- Dye, R. (1988) .Earnings Management in An Overlapping Generations Model. Journal of Accounting Research, 26 (2), 195-235.

- El Diri, M. (2017). Introduction to Earnings Management. Springer. 
- Fan, J. P. H., \&T.J. Wong (2002).Corporate Ownership Structure and the Informativeness of Accounting Earnings in East Asia. Journal of Accounting and Economics, 33(3), 401-425.

- Fan, Q. (2007). Earnings Management and Ownership Retention for Initial Public Offering Firms: Theory and Evidence. The Accounting Review, 82(1), 27-64.

- Farooq, O., and M. Benali (2012). Earnings Management Behavior of the IPO Firms during Pre-IPO, IPO, And Post-IPO Years: Evidence from the Casablanca Stock Exchange. African journal of business management, 6 (31), 9005-9014.

- Friedlan, J. (1994). Accounting Choices of Issuers of Initial Public Offerings. Contemporary Accounting Research, 11(1), 1-31.

- Giroux, G. (2004). Detecting earnings management. New Jersey: Wiley.

- Gounopoulos, D., \& H. Phamb (2018). Financial Expert CEOs and Earnings Management around Initial Public Offerings. International Journal of Accounting, 53(2), 102-117.

- Gugler, K., \&B. Yurtoglu (2003). Corporate Governance and Dividend Payout Policy in Germany. European Economic Review, 47(4), 731-758.

- Güleç, O. F., H. Temiz \& S. karacaer (2016). Earnings Management around Initial Public Offerings: Borsa Istanbul Application. Journal of Business Research Turk, 8 (4), 253-265.

- Harris, M., \& A. Raviv (1979). Optimal Incentive Contracts with Imperfect Information. Journal of Economic Theory, 20 (2), 231-259.

- Healy, P., \& J. Wahlen (1999). A Review of the Earnings Management Literature and Its Implications for Standard Setting. Accounting Horizons, 13(4), 365-383.

- Hernando, R. (2018).The Effect of Information Asymmetry on Earnings Management in Companies that Conduct an Initial Public Offering (IPO) On the Indonesia Stock Exchange (IDX). Journal of Sriwijaya Management and Business, 16(4), 222-236.

- Holmstrom, B., \& P. Milgrom (1987). Aggregation and Linearity in the Provision of Inter Temporal Incentives. Econometrica, 55(2), 303-328.

- Ibbotson, R. G. (1975).Price Performance of Common Stock New Issues. Journal of Financial Economics, 2 (3), 235-272.

- Jensen, M., \& W. Meckling (1976). Theory of the firm: Managerial behavior, agency costs, and ownership structure. Journal of Financial Economics, 3(4), 305-360.

- Johnson, S., R. La Porta, F. Lopez-de-Silanes \& A. Shleifer (2000). Tunneling. American Economic Review, 90(2), 22-27.

- Katti, S., \& B.V. Phani (2016). Underpricing of Initial Public Offerings: A Literature Review. Universal Journal of Accounting and Finance, 4(2), 35-52.

- Lasdi, L. (2013). The Effect of Information Asymmetry on Earnings Management through Accrual and Real Activities during Global Financial Crisis. Journal of Economics, Business and Accountancy Ventura, 16(2), 325-338.

- Leland, H., and D. Pyle (May 1977). Informational Asymmetries, Financial Structure, and Financial Intermediation. The Journal of Finance, 32(2), 371-387.

- Magnan, M., \& D. Cormier (1997, spring).The Impact of Forward-Looking Financial Data in IPOs on the Quality of Financial Reporting. Journal of Financial Statement Analysis, 2(3), 6-17.

- Mikkelson, W. H., P. M. Megan \& K. Shah (1997, June). Ownership and Operating Performance of Companies that Go Public. Journal of Financial Economics, 44(3), 281-307.

- Nurim, Y., S. Sunardi \& R. Raharti (2017). The Type I versus Type II Agency Conflict on Earnings Management. Jurnal Dinamika Manajemen, 8 (1), 44-58. 
- Ratnawati, V., M. A. Abdul-Hamid \&O. M. J. Popoola (2016). The Influence of Agency Conflict Types I and II on Earnings Management. International Journal of Economics and Financial Issues, 6(S4), 126-131.

- Richardson, V.J. (2000). Information Asymmetry and Earnings Management: Some Evidence. Review of Quantitative Financial and Accounting 15(4), 325- 347.

- Rock, K. (1986). Why New Issues Are Underpriced. Journal of Financial Economics, 15(1-2), 187-212.

- Roosenboom, P., T. van der Goot \& G. Mertens (2003). Earnings Management and Initial Public Offerings: Evidence from the Netherlands. International Journal of Accounting, 38(3), 243-266.

- Ronen, J., \& V. Yaari (2008). Earnings management: Emerging insights in theory, practice, and research. New York: Springer Science and Business Media, LLC.

- Rules of Listing and Delisting Securities on the Egyptian Stock Exchange. (2020). Retrieved from https://www.fra.gov.eg/content/efsa_ar/decisions/UG30742UG30743. pdf. (In Arabic).

- Sanjaya, I. (2010). Efek entrenchment dan alignment pada management laba. Disertasi Universitas Gadjah Mada.

- Schipper, K. (1989). Commentary on Earnings Management. Accounting Horizons, 3(4), 91-102.

- Shette, R., S. Kuntluru and S.R Korivi (2016). Opportunistic Earnings Management during Initial Public Offerings: Evidence from India. Review of Accounting and Finance, 15(3), 352-371.

- Siregar, B. (2008). Ekspropriasi Emerging Saham Mayoritas Dalam Struktur Ultimat. Jurnal Riset Akuntansi Indonesia, 11(3), 237-263.

- Strong, N., \& M. Walker (1987). Information and Capital Markets. Oxford: Basil Blackwell.

- Teoh, S. H., I. Welch and T.J. Wong (1998a). Earnings Management and the LongRun Market Performance of Initial Public Offerings. Journal of Finance, 53(6), 1935-1974.

- Teoh, S. H., T. J. Wong and G. R. Rao (1998b). Are Earnings during Initial Public Offerings Opportunistic? Review of Accounting Studies, 3(1-2), 175-208. 